\title{
CAUSE OF FAILURE OF A CERTAIN BUILDING AND STRATEGIES
}

\author{
Chunmei Zhang \\ Architecture and Civil Engineering School, Inner Mongolia University of Science and Technology, \\ Baotou, 014010, P.R.China \\ jpxt@163.com
}

Key words: pit supporting, soil nail, design, side slope

Abstract: Soil nail shotcrete-bolt supporting scheme is adopted in pit supporting, while side slope will destabilize and collapse because drainage of soil nail shotcrete-bolt supporting design fails to meet the design requirements. The effect required by the engineering is fulfilled by adopting the design and construction treatment scheme of light well point precipitation, gravity retaining wall outside and adding soil nail on the west side of side slope platform. This treatment method adopted can provide effective design and construction basis for pit supporting engineering.

The construction of the high-rise building and further development and utilization of underground space lead to the contradiction between urban development and scarce land resources; developing underground space becomes the effective measures to relieve lots of contradictions of urban development. Using underground space to promote the development of the pit supporting, the excavation depth and area in foundation pit engineering is increasing constantly, which promotes the development of the design and construction foundation of pit engineering [1].

Foundation pit engineering is one integrated technology related to the factors of site investigation, foundation pit design, construction, monitor, and so on. Generally, the impact on foundation pit caused by the sudden change of surrounding environment is difficult to predict and control during construction; deep foundation construction of deeper and deeper underground foundation pit will cause some impacts on the surrounding environment and cause damages to the surrounding buildings and facilities. Therefore, technology-reliable and feasible supporting structure to ensure safety should be set; retaining structure of foundation pit is crucial as well.

Soil nail supporting method also called deep foundation pit shotcrete-bolt supporting method, is an advanced method of reinforcing and supporting foundation pit side wall and rock and soils side slope, which firstly applied in Shenzhen since 1992, it has been applied widely in the country.

Engineering Design This project is to build a 20-foor office building with frame tube structure, and the building is $73.6 \mathrm{~m}$ in height and the biggest excavation depth of the basement foundation pit is $12.7 \mathrm{~m}$. Construction site is located on alluvial plain with flat terrain, which is mainly composed of silt, clay and sand loam with multiple arrangements in vertical and big changes in horizontal, the groundwater depth is $2.42 \sim 2.73 \mathrm{~m}$, draining from the south to the north. The physical properties of the soil layer refer to table 1. The surroundings of proposed site are as follows: about $6 \mathrm{~m}$ away from 3-floor office building in the east, strip footing; about $6 \mathrm{~m}$ from five-floor residential building in the south, strip footing; the small boiler in the southeastern corner; $6 \mathrm{~m}$ away from a 11-floor-built office building in the northern section of the west, pile foundation of $9 \mathrm{~m}$ in Pile length; construction site space is relatively limited. Geological data: relevant calculation parameters are determined as follows, according to geology report of the engineering and so on: the average 
specific weight of soil layer is $\gamma=20.0 \mathrm{kN} / \mathrm{m}^{3}$; the average cohesive force $c=32.0 \mathrm{kPa}$; the average angle of internal friction $\varphi=18.63^{\circ}$; Excavation depth of foundation pit $H=11.42 \mathrm{~m}$; the foundation pit grading $1: 0.18$, namely $\beta=10^{\circ}$ along with the vertical surface.

Table 1 Building field geologic stratum table

\begin{tabular}{l|l|l|l|l|l|l}
\hline Floor & Rock-soil Property & $\begin{array}{l}\text { Buried } \\
\text { Depth(m) }\end{array}$ & Color & Humidity & Density Rate & Consistence State \\
\hline 1 & Miscellaneous fill & 1.10 & Mixed & dry & loose & \\
\hline 2 & $\begin{array}{l}\text { Loess-shape silty } \\
\text { clay }\end{array}$ & $5.20-6.70$ & $\tan$ & saturated & Slightly dense & Plastic to flexible plastic \\
\hline 3 & silty clay & $7.50-8.5$ & $\tan$ & saturated & Slightly dense & Plastic to stiff plastic \\
\hline 4 & clay & $13.0-13.8$ & $\tan$ & saturated & Slightly dense & Fluid plastic \\
\hline
\end{tabular}

\section{Supporting and Drainage Scheme}

Supporting scheme: The selection of the foundation pit excavation scheme depends on the surroundings, according to the conditions of this site, due to the impossibility of the adoption of a simple slope excavation scheme and unallowance of greater deformation of soil mass around foundation pit in the process of the engineering, in this engineering, 2-floor bolts, $1.5 \mathrm{~m}$ longitudinal spacing and $2 \mathrm{~m}$ horizontal spacing, both $12 \mathrm{~m}$ in length are set in the eastern, southern, and western sides slope; 5-floor soil nail, $1.5 \mathrm{~m}$ longitudinal spacing, $2 \mathrm{~m}$ horizontal spacing, soil nail length: $8 \mathrm{~m}$ in length of the first floor; the second and third floor : $6 \mathrm{~m}$ in length; the forth floor: $5 \mathrm{~m}$ in length; the fifth floor: $3 \mathrm{~m}$ in length . In the northern side slope of foundation pit, 4-floor soil nails are designed, that is to say, 2 floors above and below step respectively, $6 \mathrm{~m}$ in length of all soil nails. Aperture of bolt and soil nail drill hole is $150 \mathrm{~mm}$ for each; the surfacing is \$6. 5 @ $200 \times 200$ steel meshes with $100 \mathrm{~mm}$ shotcrete in thickness.In the northern side slope of foundation pit, 4-floor soil nail are designed, 2 floors above and below step respectively, of which the length are all $6 \mathrm{~m}$. Aperture of bolt and soil nail drill hole is $150 \mathrm{~mm}$ for each; the surfacing is Ф6. 5 @ $200 \times 200$ steel meshes with $100 \mathrm{~mm}$ shotcrete in thickness (Figure 1a.b in reference).

Drainage scheme: according to requirements of the foundation pit slope supporting construction, groundwater should be dropped to below $-12.7 \mathrm{~m}$, and drain out gravity water from the soil before digging foundation pit. Therefore, drainage design adopts tube well drainage scheme, in which well is designed to be $20 \mathrm{~m}$ in depth, well spacing of south side of foundation pit $10 \mathrm{~m}$, both sides of east and west well spacing of foundation pit $12 \mathrm{~m}$, and north side of foundation pit $15 \mathrm{~m}$. Computing as follows [2]: based on the Rankine's earth pressure theory, if suppose earth slope sliding shear surface is a plane; the angle with horizontal plane $45^{\circ}+\frac{\varphi}{2}$, the angle of rupture is $\alpha_{f}=45^{\circ}-\frac{\varphi}{2}=35.7^{\circ}$. Active earth pressure coefficient: $k_{a}=\tan ^{2}\left(45^{\circ}-\frac{\varphi}{2}\right)=0.52, \sqrt{k_{a}}=0.72$; 
Passive earth pressure coefficient: $k_{p}=\tan ^{2}\left(45^{\circ}+\frac{\varphi}{2}\right)=1.94, \sqrt{k_{p}}=1.39$

To solve the slope stability safety coefficient by application of slices method, after anchor bolt well being set, calculate by the following formula:
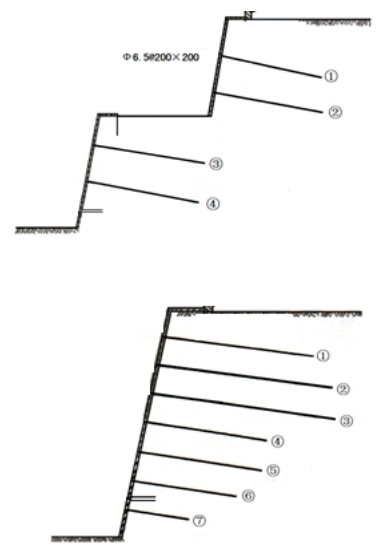

(a) east, west, south

(b) north

Figure 1 Supporting design profile of side slope

$M=\frac{f\left(\Delta N+\Delta P_{n}\right)+\sum C \cdot \Delta L \cdot \delta}{\sum \Delta T-\sum P_{t}}=1.77 \mathrm{f} 1.35$

It conforms to the requirements of the specification for temporary slope supporting.

\section{The Failure of the Soil Nailing Wall and Treatment Measures}

For the sake of saving construction cost on supporting structure, real estate developers estimate not enough for the difficulty of supporting; they change the supporting and drainage scheme on their accord, so that the original drainage and enclosure scheme failed to implement. The actual well depth is change into $14 \mathrm{~m}$; all well spacing the $10 \mathrm{~m}$. When the foundation pit digged deep to $5 \sim 6$ $\mathrm{m}$, pipes leak in the southeast and south of foundation pit; when the foundation pit digged deep to 8 $\sim 9 \mathrm{~m}$ to reach groundwater floor, the soil layer of the bottom of pit wall collapses; unable to continue construction. At this time at $3 \mathrm{~m}$ away outside of pit of the south section in the east of foundation pit appears crack paralleled to the foundation pit, about $1 \sim 2 \mathrm{~cm}$ in width. The analysis suggests problems mentioned above were caused by the failure of drainage of groundwater. Therefore another 10 drainage wells are decided to be digged in the foundation pit. In the process of construction of digging wells, big landslide occurred in the east section of the south side of pit, and the small boiler room in the corner fell into foundation pit; the ground of apartment building in the south side of foundation pit and the office in the east side appears crack paralleled to the foundation pit, about $1 \sim 3 \mathrm{~cm}$ in width, which tends to expand. Through research, the following measures are adopted: (1) stop digging; (2) continue digging Wells to drain in the foundation pit; (3) supporting reinforcement should be carried out on the side slope of landslide area, namely setting 3-layer of 20 $\mathrm{m}$ in length soil layer anchor rod, and 1 layer of $8 \mathrm{~m}$ soil nail in length, exerting pre-stress on the upper waist beam; (4) modify the original building design, namely prepare a $6 \mathrm{~m}$ wide platform, at the depth of $6 \mathrm{~m}$ digged in the south side of foundation pit.

By these treatment measures mentioned above, the upper side slope is reinforced in some degree, but groundwater still cannot drop down. The release point of groundwater is over $2 \mathrm{~m}$ higher than the designed pit base, and the foundation pit cannot continue to be digged. At this time, the building 
side with relevant units like research, design, construction etc. researched and decided to drive I-type steel pile in the east side and southern section in the west side of foundation pit to protect slope toe of the foundation pit. The i-beam piles are designed to $7 \mathrm{~m}$ in length, $3 \mathrm{~m}$ in embedded depth, and $0.8 \mathrm{~m}$ of column spacing. But in the construction, the piles cannot be driven, so the actual embedded depth of steel pile is only1 $\sim 3 \mathrm{~m}$; the upper end of steel pile is pulled by $\Phi 25$ steel bars to the soil nail, and then continue digging. When dig to the design depth, west wall displacement is found as making bed course. After soil mass flows with the groundwater, pit wall of pit bottom is emptied; the ground outside of pit cracks, of which the seam reaches $2 \sim 3 \mathrm{~cm}$ in width. As inward displacement of pit wall occurred, ground fissure expand rapidly, and large scale collapse happens in the west side of foundation pit. Then steel piles tilt to pit, which endangers 11-floor office building and boiler room in the west side. Then the construction unit organizes relevant units to study measures for emergency. Firstly, the method of unloading is applied, removing $4 \mathrm{~m}$ of soil layer above side slope to form about $2 \mathrm{~m}$ platform in width, in order to reduce the side pressure of soil. The main reason for side slope collapse is the failure of drainage of the groundwater, so the groundwater in the west slope should be drained down to stabilize the slope in the first place. For that, the light well point drainage measures are decided to be adopted, that is, two rows of well point are to be set: the first row of the well set in slope toe of the west side of foundation pit, $5 \mathrm{~m}$ of well depth, $3 \mathrm{~m}$ into the strong weathered rock, $1.5 \mathrm{~m}$ of well spacing, a total of 15 wells are set; the second row of well set on platform, $9 \mathrm{~m}$ of well depth, $2 \mathrm{~m}$ of well spacing, a total of 11 wells are set. Through the well point drainage, the water pressure at the bottom of the clay layer reduces; the pore water pressure in the west slope also reduces, so the slope stability increases. to accelerate the discharge the water of clay slope, drainage on embankment slope is applied in the west slope angle; concrete gravity wall is built outside. At the same time, 2 rows of soil nails, $10 \mathrm{~m}$ in length, are added in the west of side slope platform; $\Phi 6.5$ steel bars net are used to spray concrete.

\section{Analysis on cause of the accident}

Through the analysis of the relevant data, the main cause of landslide of the foundation pit of the engineering is alteration of the original drainage design, resulting in the failure of groundwater drainage, for supporting design of soil nailing spray anchor and physical performance parameters of the soil being used are all take the guarantee of draining the groundwater to $12.7 \mathrm{~m}$ into consideration. But the groundwater of site actually falls only to around $-8 \mathrm{~m}$, which makes some strength index of soil reduce greatly. In addition, part of water pipes around foundation pit leak, besides, heavy stuffs stacked surrounding foundation pit is also one of factors of instability foundation pit side slope.

Steel-pile supporting, added partly to prevent the soil mass of the lower part of the pit wall from collapsing, hasn't met the design requirements; after that the upper end of steel pile is mistakenly pulled to soil nail; the vibration remold the soil mass near the pit wall while piling, which makes the lower soil mass of pit wall collapse and form negative. The series of errors is also one of the important causes of landslide of foundation pit in the late period.

The landslide of foundation pit of the project caused a direct economic loss of more than 1 million RMB, meanwhile, caused damages on the surrounding pre-existing buildings in different degrees, of which the indirect economic loss is huge; it's really a profound lesson should be learned. 


\section{References:}

[1] Zong-ren Liu, Xue-yan Liu. Excavation Engineering [M]. Harbin Industrial University Press, (2008). (in Chinese). 4.

[2] Ming-hua Zhao, YuXiao. Soil Mechanics and Foundation Engineering [M]. Wuhan University of Science and Technology Press. 2010. (in Chinese).

[3] "Regulations of building foundation pit supporting technology" (JGJ 120-99). (in Chinese).

[4] Yang Cheng. The Soil Nail is Dharma in the Application of the Slope Reinforcement [J]. Construction Engineering and Design, 2014, (in Chinese).23(3). 